\title{
Studi Perbedaan Efektivitas Model Pembelajaran Kooperatif Tipe Jigsaw dan Snowball Throwing terhadap Prestasi Belajar Matematika Siswa Kelas VIII SMPN 1 Narmada
}

\author{
${\text { Nurbaeti Irmayani }{ }^{*} \text {, Ketut Sarjana }}^{2}$, Eka Kurniawan ${ }^{2}$, \\ Nyoman Sridana ${ }^{2}$ \\ ${ }^{1}$ Mahasiswa Pendidikan Matematika, Universitas Mataram, Mataram, Indonesia \\ 2 Pendidikan Matematika, Universitas Mataram, Mataram, Indonesia \\ *Corresponding Author e-mail: irmayani3696@gmail.com
}

Received: 31-01-2021; Revised: 25-03-2021; Published: 25-03-2021

\begin{abstract}
This research aims to find out whether there are differences in students' mathematics learning outcomes using the Jigsaw type cooperative learning model, with the Snowball throwing type cooperative learning model in VIII class of SMPN 1 Narmada. This type of research is an experimental. The sample class was selected using the random sampling cluster technique, with class VIII 1 was obtained as an experimental class with the Jigsaw model and VIII 2 as an experimental class with the Snowball Throwing model. The data was collected using students ${ }^{\text {ee }}$ achievement test as the instrument. The post-test with independent sample $t$ test at the significance level $5 \%$ yields $t_{\text {hitung }}>t_{\text {tabel }}$ that is 2,773 $>1,993$ which means that there is a difference between classes taught by Jigsaw and Snowball Throwing toward students' achievement on mathematics at the VIII grade students of SMPN 1 in the academic year 2019/2020. The result shows that the second experimental class obtain higher score $(88,24)$ than the first experimental class $(81,21)$.
\end{abstract}

Keywords: jigsaw learning model; snowball throwing learning model, learning achievement.

\begin{abstract}
Abstrak
Penelitian ini bertujuan untuk mengetahui perbedaan prestasi belajar matematika siswa antara kelas yang diajar dengan model pembelajaran kooperatif tipe Jigsaw dan Snowball Throwing pada siswa kelas VIII SMPN 1 Narmada. Jenis penelitian ini adalah eksperimen dengan pendekatan kuantitatif. Teknik pengambilan sampel dalam penelitian ini yaitu claster random sampling dengan kelas VIII 1 sebagai kelas eksperimen dengan model Jigsaw dan VIII 2 sebagai kelas eksperimen dengan model Snowball Throwing. Teknik pengumpulan data dalam penelitian ini adalah tes dengan instrumen berupa tes prestasi belajar. Uji hipotesis kemampuan akhir siswa (posttest) dengan uji independent sample t test pada taraf signifikansi $5 \%$ menghasilkan $t_{\text {hitung }}>t_{\text {tabel }}$ yaitu 2,773 $>1,993$ artinya terdapat perbedaan prestasi belajar matematika antara kelas yang menggunakan model Jigsaw dan Snowball Throwing pada siswa kelas VIII SMPN 1 Narmada. Hal ini terlihat dari nilai rata-rata prestasi belajar matematika siswa pada kelas eksperimen 1 $(88,24)$ lebih tinggi dari kelas eksperimen $2(81,21)$.

Kata Kunci: model pembelajaran jigsaw, snowball throwing, prestasi belajar matematika.

\section{Cara Mengutip}

Irmayani, N., Sarjana, K., \& Kurniawan, E (2020). Studi Perbedaan Efektivitas Model Pembelajaran Kooperatif Tipe Jigsaw dan Snowball Throwing terhadap Prestasi Belajar Matematika Siswa Kelas VIII SMPN 1 Narmada. Griya Journal of Mathematics Education and Application, 1(1), 11-18.
\end{abstract}




\section{PENDAHULUAN}

Salah satu komponen yang paling penting dari sistem pendidikan adalah kurikulum. Kurikulum yang saat ini diterapkan di Indonenesia adalah kurikulum 2013. Kurikulum 2013 merupakan paradigma baru dalam dunia pendidikan di Indonesia yang diharapkan akan membawa perbaikan di dunia pendidikan Indonesia. Di dalam kurikulum 2013 SMP memiliki tujuan untuk mendorong siswa mampu lebih baik dalam melakukan observasi, bertanya, bernalar, dan mengkomunikasikan (mempresentasikan) apa yang mereka peroleh atau mereka ketahui setelah menerima materi pembelajaran dan diharapkan siswa dapat memiliki kompetensi sikap keterampilan dan pengetahuan yang jauh lebih baik (Shobirin, 2016).

Pada kenyataannya kurikulum 2013 di SMPN 1 Narmada masih belum berjalan dengan baik. Sebagaimana hasil observasi awal yang dilakukan peneliti pada kelas VIII di SMPN 1 Narmada dengan menggunakan instrumen observasi yang menunjukkan bahwa aktivitas siswa dalam pembelajaran matematika dalam kategori kurang aktif, dimana dalam kurikulum 2013 lebih menuntut siswa untuk berperan aktif dalam proses pembelajaran, hal tersebut berdampak terhadap rendahnya prestasi belajar siswa. Beberapa faktor yang menjadi penyebab dari permasalahan tersebut, antara lain pembelajaran masih didominasi oleh guru yang aktif menyampaikan informasi. Oleh karena itu dapat dikatakan bahwa pembelajaran masih berpusat pada guru yang menyebabkan siswa kurang bersemangat saat pembelajaran berlangsung dan hanya terdapat satu dua orang yang aktif dalam peroses pembelajaran, kemudian interaksi siswa dengan guru yang masih rendah. Hal ini terlihat dari guru yang kurang dalam memberi motivasi kepada siswa untuk mengeluarkan pendapat dan lebih banyak siswa yang tidak menanyakan hal-hal yang belum jelas serta tidak meminta bimbingan guru sehingga sedikit siswa yang mengancungkan tangan untuk maju mengerjakan soal latihan di depan kelas. Rendahnya aktivitas siswa dilihat dari lembar observasi awal yang kemudian berdampak pada rendahnya prestasi belajar matematika siswa.

Tabel 1. Rata-Rata Nilai Ulangan Harian Semester Ganjil Mata Pelajaran Matematika Kelas VIII Tahun Ajaran 2019/2020.

\begin{tabular}{ccccc}
\hline No & Kelas & Banyak Siswa & Nilai Rata - Rata & Ketuntasan Nilai Klasikal \\
\hline 1 & VIII 1 & 38 & 58,74 & $28,95 \%$ \\
2 & VIII 2 & 38 & 57,32 & $26,32 \%$ \\
3 & VIII 3 & 37 & 58,47 & $29,73 \%$ \\
4 & VIII 4 & 38 & 57,84 & $35,14 \%$ \\
5 & VIII 5 & 39 & 57,74 & $28,21 \%$ \\
\hline
\end{tabular}

Berdasarkan Tabel 1 terlihat bahwa siswa masih belum mencapai ketuntasan klasikal, sesuai dengan pedoman pelaksanaan proses belajara mengajar dan penilaian kelas VIII SMPN 1 Narmada, disebutkan bahwa Kriteria Ketuntasan Minimum (KKM) yaitu 72 dan ketuntasan klasikalnya yaitu $85 \%$ siswa yang mendapat nilai lebih dari atau sama dengan 72 .

Berdasarkan hasil observasi awal yang dilakukan di kelas VIII, proses pembelajaran didominassi oleh guru, hal ini terlihat saat guru menyampaikan informasi dan 
menjelaskan materi pembelajaran dengan menggunakan metode konvensional atau metode ceramah. Beberapa siswa yang megalami kesulitan ketika diberi masalah/soal seperti kurang memahami langkah-langkah dalam menjawab soal. Secara umum pada proses pembelajaran, guru menyampaikan materi kemudian memberikan tugas untuk dikerjakan siswa, hal ini yang menyebabkan aktivitas dan prestasi belajar siswa rendah. Penerapan metode konvensional secara terus menerus bisa berdampak pada penurunan prestasi belajar siswa (Tayibu \& Faizah, 2021)(Ribut, 2021).

Berdasarkan hasil observasi peneliti kepada siswa kelas VIII diperoleh kesimpulan bahwa siswa-siswa tersebut memiliki potensi-potensi yang dapat dikembangkan, diantaranya adalah : 1) terdapat siswa yang memiliki kemampuan akademik yang tinggi, 2) siswa terlihat sangat antusias ketika diajari/dijelaskan oleh temannya, 3) siswa terlihat sangat antusias bertukar informasi satu dengan yang lainnya, 4) terdapat siswa yang lebih memilih bertanya kepada temannya, 5) siswa terlihat antusias, yaitu ikut membantu temannya ketika diberikan 6) terdapat beberapa siswa yang yang memiliki kemampuan mengajarkan atau menyampaikan materi pembelajaran kepada siswa lainnya.

Melihat hal tersebut guru harus melibatkan siswa secara aktif dalam peroses pembelajaran sehingga dapat membangkitkan semangat siswa dalam peroses pembelajaran, guru juga harus mampu memilih model pembelajaran yang sesuai dengan siswa agar tercipta suasana belajar yang didalamnya terjadi kegiatan aktif siswa dalam membangun makna atau pemahan terhadap suatu konsep, sehingga dalam susatu peroses pembelajaran siswa menjadi sentral dari kegitan pembelajaran tersebut. Terdapat beberapa model pembelajaran kooperatif yang bisa diterapkan guru dalam peroses pembelajaran, anatara lain model pembelajaran kooperatif tipe Jigsaw dan model pembelajaran koopertaf tipe Snowball Throwing.

Model pembelajaran Jigsaw adalah salah satu model pembelajaran kooperatif yang menekankan pada sikap atau perilaku bersama dalam bekerja atau membantu diantara sesama dalam struktur kerja sama yang teratur dalam kelompok, yang terdiri dari empat orang atau lebih. Model pembelajaran Jigsaw mendorong siswa aktif dan saling membantu dalam menguasai materi pembelajaran untuk mencapai tujuan pembelajaran. Kelebihan dari model pembelajaran kooperatif tipe Jigsaw adalah memunkinkan siswa untuk dapat mengembangkan kreativitas, kemampuan, dan daya pemecahan masalah menurut kehendaknya sendiri (Yuliati, 2015).

Model Pembelajaran Snowball Thorwing adalah model pembelajaran kooperatif yang menggali potensi kepemimpinan siswa dalam kelompok dan keterampilan membuat dan menjawab pertanyaan yang dipadukan melalui permainan imajinatif membentuk dan melempar bola salju. Kelebihan dari model pembelajaran kooperatif tipe Snowball Throwing adalah membangkitkan keberanian siswa untuk mengemukakan pertanyaan baik kepada guru maupun siswa lainnya dan juga dapat melatih siswa untuk menjawab pertanyaan yang diajukan guru maupun temannya dengan baik. 
Tabel 2. Langkah-langkah model pembelajaran kooperatif tipe Jigsaw

\begin{tabular}{|c|c|}
\hline Fase-Fase & Perilaku Guru \\
\hline $\begin{array}{l}\text { Fase 1: } \\
\text { Menyampaikan tujuan dan motivasi }\end{array}$ & $\begin{array}{l}\text { Guru menyampaikan tujuan pelajaran yang } \\
\text { ingin dicapai selama pembelajaran dan } \\
\text { memotivasi siswa. }\end{array}$ \\
\hline $\begin{array}{l}\text { Fase 2: } \\
\text { Mengorganisasikan siswa ke dalam } \\
\text { kelompok asal dan pembagian kelompok } \\
\text { ahli }\end{array}$ & $\begin{array}{l}\text { Siswa dikelompokkan dalam } 4-6 \text { anggota tim } \\
\text { dan tiap orang dalam tim diberi bagian materi } \\
\text { yang ditugaskan sebagai tim ahli. }\end{array}$ \\
\hline Fase 3: & berdiskusi \\
\hline Diskusi kelompok ahli & $\begin{array}{l}\text { berdasarkan kesamaan materi yang diberikan } \\
\text { pada masing-masing siswa. }\end{array}$ \\
\hline Fase 4: & Siswa dari masing-masing tim ahli berdiskusi \\
\hline Diskusi kelompok besar/asal & $\begin{array}{l}\text { kembali dalam kelompok asalnya masing- } \\
\text { masing berdasarkan ketentuan guru. }\end{array}$ \\
\hline Fase 5: & Guru membimbing kelompok untuk \\
\hline Disku & melakukan presentasi. \\
\hline Fase 6 & Guru melakukan penilaian untuk mengukur \\
\hline Pemberian kuis individu semua materi & $\begin{array}{l}\text { kemampuan dan hasil belajar siswa mengenai } \\
\text { seluruh pembahasan. }\end{array}$ \\
\hline $\begin{array}{l}\text { Fase 7: } \\
\text { Pemberian penghargaan }\end{array}$ & Memberikan penghargaan kepada kelompok \\
\hline
\end{tabular}

Tabel 3. Langkah-langkah model pembelajaran kooperatif tipe Snowball Throwing (Shoimin, 2013)

\begin{tabular}{|c|c|}
\hline Fase & Tingkah Laku Guru \\
\hline $\begin{array}{l}\text { Fase } 1 \\
\text { Menyampaikan tujuan } \\
\text { dan memotivasi siswa }\end{array}$ & $\begin{array}{l}\text { Menyampaikan seluruh tujuan dalam pem-belajaran dan } \\
\text { memotivasi siswa. }\end{array}$ \\
\hline $\begin{array}{l}\text { Fase } 2 \\
\text { Menyajikan informasi }\end{array}$ & $\begin{array}{l}\text { Menyajikan informasi mengenai materi pemebelajaran } \\
\text { siswa }\end{array}$ \\
\hline $\begin{array}{l}\text { Fase } 3 \\
\text { Mengorganisasikan } \\
\text { siswa ke dalam } \\
\text { kelompok-kelompok } \\
\text { belajar }\end{array}$ & $\begin{array}{l}\text { Membagi siswa ke dalam kelompok-kelompok belajar yang } \\
\text { terdiri dari 5-6 orang siswa. }\end{array}$ \\
\hline $\begin{array}{l}\text { Fase } 4 \\
\text { Membimbing kelompok } \\
\text { bekerja dan belajar }\end{array}$ & $\begin{array}{l}\text { Memanggil ketua kelompok dan menjelaskan materi serta } \\
\text { pembagian tugas kelompok } \\
\text { Meminta ketua kelompok kembali ke kelompoknya } \\
\text { masing-masing untuk mendisusikan tugas yang diberikan } \\
\text { guru dengan anggota kelompok } \\
\text { Memberikan selembar kertas kepada setiap kelompok dan } \\
\text { meminta kelompok tersebut menulis pertanyaan sesuai } \\
\text { dengan materi yang dijelaskan guru. } \\
\text { Meminta setiap kelompok untuk menggulung dan } \\
\text { melemparkan pertanyaan yang telah ditulis pada kertas } \\
\text { kepada kelompok lain. }\end{array}$ \\
\hline
\end{tabular}


Meminta setiap kelompok menuliskan jawaban atas pertanyaan yang didapatkan dari kelompok lain pada kertas kerja tersebut.

Fase 5

Diskusi Kelas

Guru membimbing siswa untuk melakukan diskusi kelas

Fase 6 dengan menunjuk beberapa siswa untuk mempresntasikan pekerjaannya.

Evaluasi

\section{METODE}

Jenis penelitian yang digunakan adalah quasi experimental. Penelitian ini dilaksanakan di SMPN 1 Narmada. Populasi pada penelitian ini yaitu seluruh siswa kelas VIII SMPN 1 Narmada tahun pelajaran 2019/2020.Teknik pengambilan sampel yang digunakan adalah cluster random sampling. Sampel penelitian ini berjumlah 76 siswa yang tersebar kedalam 2 kelas, dimana kelas VIII 1 sebagai kelas eksperimen 1 dengan jumlah siswa sebanyak 38 dan kelas VIII 2 sebagai kelas eksperimen 2 dengan jumlah siswa sebanyak 36 siswa.Pada penelitian ini, proses pembelajaran di kelas eksperimen 1 menggunakan model pembelajaran kooperatif tipe Jigsaw, sedangkan di kelas eksperimen 2 menggunakan model pembelajaran kooperatif tipe Snowball Throwing. Penelitian ini dilakukan sebanyak tiga kali pertemuan pada masing-masing kelas eksperimen,dimana tiga kali pertemuan tersebut terdiri dari dua kali pertemuan untuk melakukan proses pembelajaran dan satu kali digunakan untuk melakukan post test. Sebelum melakukan penelitian peneliti melakukan pengujian instrument dengan menggunakan uji validitas isi. Instrumen penelitian divalidasi oleh dua orang dosen pendidikan matematika FKIP Universitas Mataram dengan hasil validasi bahwa intsrumen yang digunakan telah valid atau layak digunakan.

Teknik analisis data yang digunakan dalam penelitian ini adalah teknik statistik deskriptif dan infrensial. Analisis statistik deskriptif digunakan untuk mendeskripsikan hasil belajar matematika siswa yang diperoleh dari kedua kelas eksperimen. Untuk mendeskripsikan hasil beajar tersebut maka diperlukan penyajian data melalui perhitungan mean, dan standar deviasi.

Sedangkan teknik statistik infrensial digunakan untuk menguji hipotesis penelitian. Namun sebelumnya dilakukan terlebih dahulu uji prasyarat analisis yaitu uji normalitas dan uji homogenitas. Adapun perumusan hipotesis penelitian ini adalah:

$H_{0}$ : Tidak terdapat perbedaan yang signifikan antara prestasi belajar matematika dengan menggunakan model pembelajaran kooperatif tipe Jigsaw dan model pembelajaran kooperatif tipe Snowball Throwing pada kelas VIII di SMPN 1 Narmada.

$H_{1}$ : Terdapat perbedaaan yang signifikant antara prestasi belajar matematika dengan menggunakan model pembelajaran kooperatif tipe Jigsaw dan model pembelajaran kooperatif tipe Snowball Throwing pada kelas VIII di SMPN 1 Narmada. 


\section{HASIL DAN PEMBAHASAN}

\subsection{Analisis statistik deskripsi data hasil penelitian}

Tabel 4. Perbandingan Hasil Belajar Matematika Siswa

\begin{tabular}{lcc}
\hline \multicolumn{1}{c}{ Deskripsi } & Kelas Jigsaw & Kelas Snowball \\
\hline Nilai Tertingggi & 100 & 100 \\
Nilai Terendah & 65 & 35 \\
Rata-rata & 88,23 & 81,21 \\
Jumlah Peserta Didik yang & 38 & 38 \\
Mengikuti Tes & & 72 \\
KKM & 72 & \\
\hline
\end{tabular}

Berdasarkan data pada tabel dapat dilihat bahwa kelas jigsaw memiliki rata-rata nilai yang lebih tinggi dari pada kelas Snowball Throwing. Jika dilihat dari ketuntasan belajar, siswa dikatakan tuntas jika nilai yang di capai $\geq 72$.

\subsection{Analisis statistik inferensial}

\subsubsection{Uji Normalitas}

Pada penelitian ini peneliti menggunakan uji One-Sample Kolmogorov-Smirnov Test, setelah dilakukan perhitungan uji normalitas diperoleh data seperti yang disajikan pada tabel berikut:

Tabel 5. Hasil Uji Normalitas Posttest Prestasi Belajar Matematika One-Sample Kolmogorov-Smirnov Test

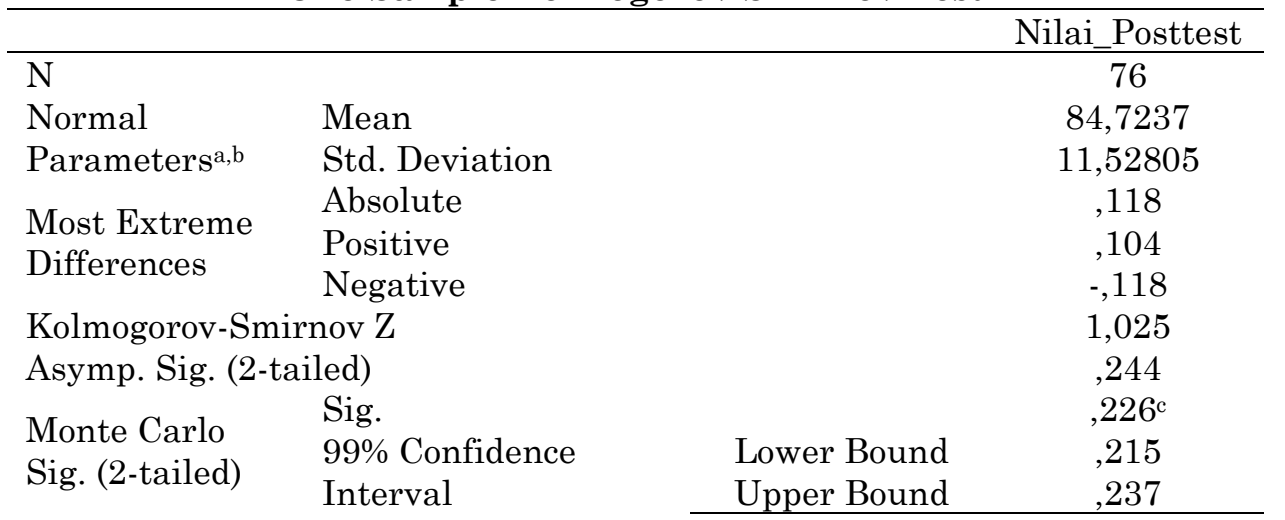

a. Test distribution is Normal.

b. Calculated from data.

Berdasarkan tabel 3 dapat dilihat bahwa nilai Asymp. Sig. (2-tailed) 0,244 > taraf signifikansi $(\alpha=0,05)$, sehingga dapat disimpulkan bahwa data penelitian terdistribusi normal. 


\subsubsection{Uji Homogenitas}

Pada penelitian ini peneliti menggunakan uji Test of Homogeneity of Variances, setelah dilakukan perhitungan uji homogenitas diperoleh data seperti yang disajikan pada tabel berikut:

\begin{tabular}{cccc}
\multicolumn{4}{c}{ Tabel 6. Hasil Uji Test of Homogeneity of Variances } \\
\hline $\begin{array}{c}\text { Levene } \\
\text { Statistic }\end{array}$ & df1 & df2 & Sig. \\
\hline 0.709 & 1 & 74 & 0.403 \\
\hline
\end{tabular}

Berdasarkan tabel 6 dapat dilihat bahwa nilai Sig sebesar 0,403 > taraf signifikansi $(\alpha=0,05)$, sehingga dapat disimpulkan bahwa data penelitian homogen.

\subsubsection{Uji Hipotesis Penelitian}

Untuk melihat perbedaan signifikan prestasi belajar matematika siswa kelas jigsaw kelas dan kelas Snowball Throwing maka dilakukan uji t dengan uji Independent Sampel t Test. Diperoleh nilai thitung sebesar 2,773, sedangkan nilai tabel pada taraf signifikansi 5\% adalah sebesar 1,993. Karena 2,773>1,993 maka $\mathrm{H}_{0}$ ditolak dan $\mathrm{H}_{1}$ diterima. Oleh karena itu, dapat disimpulkan terdapat perbedaan yang signifikan antara prestasi belajar matematika kelas Jigsaw dan kelas Snowball Throwing pada siswa kelas VIII SMPN 1 Narmada tahun pelajaran 2019/2020.

Berdasarkan hsasil observasi menunjukkan bahwa kelas VIII 1 dan kelas VIII 2 tidak memiliki perbedaan pada kemampuan awal, sehingga dapat disimpulkan bahwa kemampuan awal kelas VIII 1 dan kelas VIII 2 masih dalam kondisi yang sama atau homogen, sehingga kedua kelas tersebut dapat digunakan sebagai kelas eksperimen 1 dan kelas eksperimen 2 .

Berdasarkan hasil observasi aktivitas guru dalam proses pembelajaran diketahuai bahwa pada pertemuan pertama guru kesulitan pada saat melaksanakan kegiatan orientasi peserta didik kepada masalah baik untuk kelas Jigsaw maupun kelas Snowball hal tersebut dikarenakan guru mengalami kesulitan saat mengarahkan siswa untuk melakukan tanya jawab terkait materi yang diamati dikarenakan siswa belum mampu beradaptasi sepenuhnya terhadap model pembelajaran Jigsaw maupun Snowball sehingga menyebabkan kelas menjadi ribut. Pada tahap mengakhiri proses pembelajaran pada kelas Snowball guru kesulitan mengendalikan siswa yang ribut keluar kelas pada akhir pembelajaran.

Tabel 5. Aktivitas Siswa dalam Proses Pembelajaran

\begin{tabular}{lcccc}
\hline \multicolumn{1}{c}{ Aktivitas Siswa } & \multicolumn{4}{c}{ Skor yang diperoleh } \\
& Kelas Jigsaw & \multicolumn{2}{c}{ Kelas Snowball } \\
& 2,7 & 3,0 & 1,7 & 3,0 \\
\hline $\begin{array}{l}\text { Kesiapan siswa dalam } \\
\text { mengikuti pembelajaran }\end{array}$ & 2,0 & 3,0 & 1,0 & 2,7 \\
$\begin{array}{l}\text { Orientasi siswa terhadap } \\
\text { masalah }\end{array}$ & & Pertemuan 2 & Pertemuan 1 & Pertemuan 2 \\
\hline
\end{tabular}




\begin{tabular}{|c|c|c|c|c|}
\hline $\begin{array}{l}\text { Mengorganisasikan } \\
\text { peserta didik untuk } \\
\text { belajar }\end{array}$ & 1,33 & 3,0 & 1,33 & 2,3 \\
\hline $\begin{array}{l}\text { Membimbing } \\
\text { penyelidikan individu } \\
\text { dalam kelompok }\end{array}$ & 1,33 & 2,75 & 1,75 & 2,75 \\
\hline $\begin{array}{l}\text { Mengembangkan dan } \\
\text { menyajikan hasil karya }\end{array}$ & 0,75 & 2,75 & 1,5 & 2,75 \\
\hline $\begin{array}{l}\text { Menganalisis dan } \\
\text { mengevaluasi proses } \\
\text { pemecahan masalah }\end{array}$ & 1,0 & 2,25 & 1,75 & 2,25 \\
\hline $\begin{array}{l}\text { Partisipasi siswa dalam } \\
\text { menyimpulkan hasil } \\
\text { pembelajaran }\end{array}$ & 0,75 & 3,0 & 1,0 & 2,7 \\
\hline $\begin{array}{l}\text { Rata-rata masing-masing } \\
\text { pertemuan }\end{array}$ & 1,41 & 2,82 & 1,43 & 2,6 \\
\hline Rata-rata & \multirow{2}{*}{\multicolumn{2}{|c|}{$\begin{array}{c}2,12 \\
\text { Aktif }\end{array}$}} & \multirow{2}{*}{\multicolumn{2}{|c|}{$\begin{array}{c}2,02 \\
\text { Aktif }\end{array}$}} \\
\hline Kesimpulan & & & & \\
\hline
\end{tabular}

Berdasarkan tabel 5 dapat dilihat perbedaan skor aktivitas siswa antara kelas Jigsaw dan kelas Snowball pada pertemuan 1 maupun pertemuan 2, dimana kedua kelas samasama meningkatkan aktivitas belajar siswa, namun dari tabel dapat dilihat bahwa skor rata-rata yang diperoleh kelas Jigsaw lebih tinggi dari skor yang diperoleh kelas Snowball, hal tersebut disebabkan karena pada tahap mengorganisasikan siswa terhadap masalah pertemuan 2 pada kelas Jigsaw siswa lebih antusias dibandingkan dengan kelas Snowball. Hal ini sesuai dengan pendapat (Slavin, 2009), yaitu salah satu kelebihan dari Model pembelajaran kooperatif Tipe Jigsaw yaitu dengan melibatkan siswa secara aktif dalam proses pembelajran, model pembelajaran kooperatif tipe Jigsaw melibatkan siswa secara aktif dalam proses pembelajaran sehingga model Jigsaw akan lebih menarik dan tidak monoton dibandingkan dengan metode konvesional.

Pada tahap mengorganisasikan siswa untuk belajar dan diskusi kelas pertemuan 2 pada kelas Jigsaw lebih efektif karena semua siswa aktif sebagai tutor sebaya yang harus memahami secara mendalam materi bagian masing-masing siswa. Hal ini sesuai dengan pendapat (Slavin, 2009) yang menyatakan bahwa siswa aktif berperan sebagai tutor sebaya untuk meningkatkan keberhasilan kelompok, terjadi interaksi antar siswa seiring dengan kemampuan mereka dalam berpendapat (Slavin, 2009).

Pada tahap menyimpulkan hasil pembelajaran, partisipasi siswa dalam menyimpulkan hasil pembelajaran pada kelas Jigsaw lebih tinggi dikarenakan semua siswa aktif bertanya dan memberi pendapat pada saat diskusi kelas. Hal ini sesuai dengan pendapat Slavin yang menyatakan bahwa penerimaan terhadap individu lebih besar, karena dengan pembelajaran Jigsaw semua siswa akan terlibat aktif dalam permasalahan yang diberikan guru (Slavin, 2009).

Sedangkan pada kelas Snowball pada tahap membimbing penyelidikan individu dalam kelompok pada pertemuan 1 skornya lebih tinggi dibandingkan dengan kelas Jigsaw, hal ini dikarenakan pada kelas Snowball siswa sudah terbiasa belajar dan bekerja dalam 
satu kelompok berbeda dengan kelas Jigsaw yang terdiri dari kelompok asal dan kelompok ahli.

Pada tahap mengembangkan dan menyajikan hasil karya pertemuan 1 kelas Snowball skornya lebih tinggi dikarenakan siswa sudah terbiasa belajar dalam kelompok sehingga saat diskusi kelas berlangsung mereka sudah mempersiapkan materi yang akan disampaikan, berbeda dengan kelas Jigsaw mereka masih kebingungan kelompok yang akan presentasi antara kelompok asal atau kelompok ahli.

Pada tahap menganalisis dan mengevaluasi proses pemecahan masalah skor kelas Snowball pada pertemuan 1 lebih tinggi dibandingkan kelas Jigsaw dikarenakan pada awal pertemuan kelas Jigsaw belum mampu beradaptasi sepenuhnya terhadap model yang diterapkan.

Dari tabel 6 juga dapat lihat bahwa masing-masing model Jigsaw maupun Snowball Throwing sama-sama meningkatkan aktivitas siswa dalam proses pembelajaran sehingga dapat meningkatkan prestasi belajar matematika siswa. Sesuai dengan pendapat (Rusman, 2017), yaitu model pembelajaran kooperatif tipe Jigsaw merupakan salah satu model pembelajaran kooperatif yang mendorong siswa aktif dan saling membantu dalam menguasai materi pelajaran untuk mencapai prestasi yang maksimal (Rusman, 2017). Hal ini juga dikuatkan oleh penelitian dari (Jannah, 2009) yang menyimpulkan bahwa pembelajaran kooperatif tipe Jigsaw efektif digunakan dalam proses pembelajaran matematika materi pokok Komposisi Fungsi (Jannah, 2009).

Dilihat dari tabel 5 model pembelajaran kooperatif tipe Snowball Throwing juga dapat meningkatkan aktivitas siswa dalam proses pembelajaran, hal ini juga sesuai dengan pendapat Komala Sari, yaitu Snowball Throwing adalah suatu tipe model pembelajaran kooperatif yang menggali potensi kepemimpinansi siswa dalam kelompok dan keterampilan membuat-menjawab pertanyaan yang dipadukan mlelalui permainan imajinatif membentuk dan melempar bola salju yang nantinya akan mampu meningkatkan prestasi belajar siswa (Komalasari, 2017). Hal ini juga dikuatkan oleh penelitian yang dilakukan oleh yang menyimpulkan bahwa model pembelajaran kooperatif tipe Snowball Throwing pada materi sistem pertidaksamaan linier dapat meningkatkan hasil belajara siswa s.

Dari hasil penelitian diperoleh nilai rata-rata kelas Jigsaw lebih tinggi dibandingkan kelas Snowball Throwing, hal ini salah satunya disebabkan karena skor aktivitas siswa dalam proses pembelajaran kelas Jigsaw lebih tinggi dibandingkan kelas Snowball Throwing sehingga prestasi belajar matematikanya pun lebih tinggi. Hal ini juga sesuai dengan pendapat (Rusman, 2017), yang menerangkan bahwa kelebihan model kooperatif tipe Jigsaw, yaitu meningkatkan hasil belajar siswa dan meningkatkan daya ingat siswa (Rusman, 2017). (Slavin, 2009) juga berpendapat bahwa model Jigsaw dapat meningkatkan hasil belajar lebih mendalam, karena dengan pembelajaran Jigsaw perkembangan hasil belajar siswa dapat diidentifikasikan secara bertahap, sehingga pada akhir pembelajaran hasil yang diperoleh siswa dapat lebih optimal (Slavin, 2009). 


\section{PENUTUP}

Berdasarkan analisis data dan pembahasan maka dapat disimpulkan bahwa terdapat perbedaan yang signifikan antara prestasi belajar matematika siswa kelas Jigsaw dan kelas Snowball Throwing pada siswa kelas VIII SMPN 1 Narmada tahun pelajaran $2019 / 2020$.

\section{REFERENSI}

Jannah, U. (2009). Efektivitas pembelajaran kooperatif tipe jigsaw terhadap hasil belajar peserta didik materi pokok komposisi fungsi semester 2 kelas XI MAN Kendal tahun pelajaran 2007/2008. UIN Walisongo.

Komalasari, K. (2017). Pembelajaran kontekstual: konsep dan aplikasi.

Ribut, O. (2021). Pengaruh Model Pembelajaran Kooperatif Think Pair Share (TPS) Pada Prestasi matematika Siswa Sekolah Menengah Pertama. Jurnal Jendela Pendidikan, 1(1), 1-6.

Rusman. (2017). Belajar \& Pembelajaran: Berorientasi Standar Proses Pendidikan. Prenada Media.

Shobirin, M. (2016). Konsep dan Implementasi Kurikulum 2013 di Sekolah Dasar. Yogyakarta: Deepublish.

Shoimin, A. (2013). model pembelajaran inovatif dalam kurikulum 2013. Yogyakarta: Ar-Ruzz Media.

Slavin, R. E. (2009). Cooperative learning teori, riset dan praktik. Bandung: Nusa Media, 236.

Tayibu, N. Q., \& Faizah, A. N. (2021). Efektivitas Pembelajaran Matematika melalui Metode Penemuan Terbimbing Setting Kooperatif. Mosharafa: Jurnal Pendidikan Matematika, 10(1), 117-128.

Yuliati. (2015). Efektifitas Penggunaan Model Kooperatif Tipe Snowball Throwing Untuk Meningkatkan Hasil Belajar Siswa Pada Materi Sistem Pertidaksamaan Linear di Kelas XIIS-2 SMA Negeri 7 Banda Aceh. Peluang, 3(2). 